Malim Soleh Rambe, M.Pd.Kons ${ }^{1}$ Nevi Yarni ${ }^{2}$

\section{PENGARUH GAYA BELAJAR VISUAL, AUDITORIAL, DAN KINESTETIK TERHADAP PRESTASI BELAJAR SISWA SMA DIAN ANDALAS PADANG}

\begin{abstract}
Abstrak
Penelitian ini bertujuan mendeskripsikan pengaruh gaya belajar visual, auditorial, dan kinestetik terhadap prestasi belajar siswa pada Jurusan IPA SMA Dian Andalas Padang. Pengumpulan data dilakukan dengan angket dan dokumentasi. Populasi berjumlah 135 orang dan sampel berjumlah 110 orang yang ditentukan dengan teknik proportionate stratisfied random sampling. Uji hipotesis dilakukan dengan analisis regresi linear berganda dan sederhana dengan taraf signifikansi 0,05. Hasil penelitian sebagai berikut. Pertama, terdapat pengaruh yang signifikan gaya belajar visual, auditorial dan kinestetik terhadap prestasi belajar. Kedua, terdapat pengaruh signifikan gaya belajar visual terhadap prestasi belajar. Ketiga, terdapat pengaruh yang signifikan gaya belajar auditorial terhadap prestasi belajar. Keempat, terdapat pengaruh yang signifikan gaya belajar kinestetik terhadap prestasi belajar. Kelima, hasil uji determinasi menunjukkan sumbangan relatif gaya belajar visual, auditorial, dan kinestetik terhadap prestasi belajar siswa sebesar 33,8\%. Sumbangan relatif masingmasing terhadap prestasi belajar, yakni: gaya belajar visual $27,4 \%$, gaya belajar auditorial $23,2 \%$, dan gaya belajar kinestetik $27,2 \%$.
\end{abstract}

Kata kunci: Gaya Belajar Visual, Gaya Belajar Auditorial, Gaya Belajar Kinestetik

\begin{abstract}
This study was aimed at finding the effects of visual, audio and kinestetic learning styles on the acadion the academic achievement of students of the Science School Dian Andalas of Padang. Data were collected from questionnaires and documents. A sample of 110 students were selected out of 135 students using the proportional stratisfied random sampling technique. Hypothesis testing was done using the simple linear multiregression statitic at the 0,5 significance level. Research results show : First, there is a significant effect of visual, audio, and kinestetic learning style on learning achievement; Second there is a significant effect on visual learning style on learning achievement; Third, there is a significant effect of audio learning style of learning achievement; Fourth, there is a significant effect of kinestetic learning style on learning achievement on learning achievement; Fifth, determinant analysis shows relative contribution of $33.8 \%$ of visual, audio, and kinestetic learning styles on learning achievement, while individual contributions were: visual $=27.4 \%$, audio $=23.2 \%$, and kinestetic $=27.2 \%$.
\end{abstract}

Keywords: Visual Learning Style, Audio Learning Style, Kinestetik Learning Style

${ }^{1}$ Mahasiswa Prodi Ilmu Pendidikan, Universitas $\quad$ Negeri $\quad$ Padang $\quad$ Alamat email
malimsolehrambe78@gmail.com
${ }^{2}$ Dosen/Staf Pengajar Prodi Ilmu Pendidikan, Universitas Negeri Padang




\section{PENDAHULUAN}

Gaya belajar merupakan cara termudah yang dimiliki oleh individu dalam menyerap, mengatur, dan mengolah informasi yang diterima. Gaya belajar yang sesuai adalah kunci keberhasilan siswa dalam belajar. Dengan menyadari hal ini, siswa mampu menyerap dan mengolah informasi dan menjadikan belajar lebih mudah dengan gaya belajar siswa sendiri. Penggunaan gaya belajar yang dibatasi hanya dalam satu bentuk, terutama yang bersifat verbal atau dengan jalur auditorial, tentunya dapat menyebabkan adanya ketimpangan dalam menyerap informasi. Oleh karena itu, dalam kegiatan belajar, siswa perlu dibantu dan diarahkan untuk mengenali gaya belajar yang sesuai dengan dirinya sehingga tujuan pembelajaran dapat dicapai secara efektif.

Terdapat tiga modalitas (type) dalam gaya belajar yaitu visual, auditorial, dan kinestetik (Deporter \& Hernacki, 2000). Banyak ahli lainnya yang mengategorikan gaya belajar berdasarkan preferensi kognitif, profil kecerdasan dan prefensi sensori. Dalam penelitian ini, menggunakan preferensi sensori yaitu gaya belajar visual, auditorial, dan kinestetik. Alasan digunakannya preferensi sensori karena dalam proses kegiatan belajar siswa dapat diamati melalui alat indera. Berdasarkan preferensi sensori, pelajar visual belajar melalui sesuatu yang mereka lihat, auditorial belajar dengan cara mendengar, dan kinestetik belajar dengan gerak, bekerja, dan menyentuh. Setiap siswa memiliki ketiga gaya belajar tersebut, hanya saja satu gaya biasanya lebih mendominasi. Prestasi belajar adalah suatu penilaian akhir dari proses dan pengenalan yang telah dilakukan berulang-ulang serta akan tersimpan dalam waktu yang lama karena hasil belajar turut serta dalam membentuk pribadi individu yang selalu ingin mencapai hasil yang lebih baik lagi sehingga akan mengubah cara berpikir serta menghasilkan perilaku kerja yang lebih baik (Hamalih, 2001).

Siswa pada Jurusan IPA SMA Dian Andalas Padang memiliki kegiatan belajar di kelas dan laboratorium praktik. Kegiatan belajar ini menuntut siswa menggunakan gaya belajarnya secara optimal sehingga tercapai hasil yang efektif. Penelitian mengenai gaya belajar siswa belum pernah dilakukan oleh peneliti lainnya. Berdasarkan observasi awal yang dilakukan peneliti, siswa pada Jurusan IPA SMA Dian Andalas Padang belum memahami gaya belajarnya masing-masing sehingga siswa belum dapat memaksimalkannya dalam proses belajar. Ditemukan juga gaya belajar siswa yang beragam. Oleh karena itu, perlu diteliti secara mendalam gaya belajar dari masing-masing siswa dan bagaimana pengaruh gaya belajar visual, auditorial, dan kinestetik terhadap prestasi belajar siswa?

Berdasarkan masalah di atas, peneliti tertarik untuk melakukan penelitian dengan judul "Pengaruh Gaya Belajar Visual, Auditorial dan Kinestetik Terhadap Prestasi Belajar Siswa Pada Jurusan IPA SMA Dian Andalas Padang Tahun Ajaran 2019/2020". Rumusan masalah dalam penelitian ini meliputi sejauh mana gaya belajar visual, auditorial, dan kinestetik secara bersama- sama mempengaruhi prestasi belajar siswa pada Jurusan IPA SMA Dian Andalas Padang, serta bagaimana gaya belajar visual, auditorial, dan kinestetik secara masing-masing mempengaruhi prestasi belajar siswa pada Jurusan IPA SMA Dian Andalas Padang.

\section{METODE}

Populasi dalam penelitian ini adalah siswa pada Jurusan IPA SMA Dian Andalas Padang yang berjumlah 135 siswa yang tersebar pada dua kelas, yaitu X IPA dan XI IPA. Jumlah populasi sebanyak 135 orang, maka untuk menentukan jumlah sampel digunakan teknik proportionate stratisfied random sampling dengan tingkat presisi sebesar 5\% dan setelah dihitung, sampel dalam penelitian ini berjumlah 110 orang. Teknik pengumpulan data yang digunakan dalam penelitian ini adalah kuesioner dan dokumentasi. Kuesioner yang digunakan dirancang dengan menggunakan skala Likert, untuk mengumpulkan data tentang gaya belajar visual, gaya belajar auditorial, dan gaya belajar kinestetik yang merupakan variabel independen dalam penelitian ini. Dokumentasi digunakan untuk mengumpulkan data tentang prestasi belajar siswa yang merupakan variabel dependen dalam penelitian ini.

Data yang diperoleh dianalisis dengan menggunakan analisis regresi linear berganda untuk menganalisis pengaruh gaya belajar visual, auditorial, dan kinestetik secara bersama- 
sama terhadap prestasi belajar, serta analisis regresi linear sederhana untuk menganalisis pengaruh gaya belajar visual, auditorial, dan kinestetik secara masing-masing terhadap prestasi belajar siswa. Kedua analisis tersebut dilakukan dengan bantuan Program SPSS 17.0 (Statistical Product and Service Solution).

\section{HASIL DAN PEMBAHASAN}

Gaya belajar visual, auditorial, dan kinestetik merupakan suatu kombinasi dari bagaimana siswa menyerap, mengatur, dan mengolah informasi yang pada akhirnya akan mempengaruhi prestasi belajar siswa. Hasil penelitian menunjukkan bahwa gaya. belajar visual, gaya belajar auditorial, dan gaya belajar kinestetik memiliki hubungan positif dengan prestasi belajar. Koefisien gaya belajar visual sebesar 0,080; gaya belajar auditorial sebesar 0,043; dan gaya belajar kinestetik 0,079. Artinya, semakin meningkat penggunaan gaya belajar visual, gaya belajar auditorial, dan gaya belajar kinestetik maka semakin meningkat prestasi belajar siswa. Hasil penelitian ini menunjukkan bahwa pengaruh gaya belajar visual, gaya belajar auditorial, dan gaya belajar kinestetik terhadap prestasi belajar berada pada kategori sangat kuat (Sugiyono, 2007 dalam Priyatno, 2008: 78).

Kecenderungan seseorang untuk belajar sangat beragam dan dipengaruhi oleh beberapa hal. Cara seseorang menyerap informasi, mengolahnya, dan memanifestasikan dalam wujud nyata perilaku hidupnya disebut dengan gaya/tipe belajar. Setiap orang memiliki gaya dan tipologi belajar yang berbeda-beda, tetapi mungkin juga ada yang memiliki gaya/tipologi belajar sejenis. Pada kenyataannya, gaya dan tipologi belajar berpengaruh terhadap hasil yang diperolehnya. Dalam realitas kehidupan sehari-hari, ada orang yang mudah menerima informasi baru dengan mendengarkan langsung dari sumbernya, ada yang cukup dengan tulisan atau memo, dan ada yang harus didemonstrasikan aktivitasnya.

Hal tersebut menunjukkan adanya gaya/ tipe belajar pada manusia. Gaya/tipologi belajar dapat dibagi menjadi tiga. Hal ini didasarkan pada cara seseorang menyerap informasi, mengolah, dan menyampaikannya, serta secara universal atau bagaimana seseorang tersebut belajar (Ula, 2013: 31). Gaya belajar merupakan metode yang dimiliki individu untuk mendapatkan informasi yang pada prinsipnya gaya belajar merupakan bagian integral dalam siklus belajar aktif. Pada awal pengalaman belajar, salah satu di antara langkah pertama adalah mengenali modalitas atau gaya belajar yang dimiliki, apakah gaya belajar visual, auditorial, atau kinestetik (Hasrul, 2009). Ketiga gaya dan tipologi belajar tersebut, tidak memberikan arti bahwa setiap individu atau seseorang hanya memiliki satu cara dan tipe belajar tertentu sehingga tidak memiliki cara dan tipe belajar yang lain.

Teori-teori di atas mengenai gaya belajar visual, gaya belajar auditorial, dan gaya belajar kinestetik yang mempengaruhi prestasi belajar siswa, mendukung hasil penelitian ini, yaitu variabel Gaya Belajar Visual (X1), Gaya Belajar Auditorial (X2) dan Gaya Belajar Kinestetik (X3) secara bersama-sama berpengarus secara positif dan signifikan terhadap variabel Prestasi Belajar (Y) siswa pada Jurusan IPA SMA Dian Andalas Padang Tahun Ajaran 2019/2020 dengan persentase sebesar 62,91\%, sedangkan sisanya 37,09\% diprediksi dipengaruhi oleh faktor lain yang tidak diteliti dalam penelitian ini, misalnya faktor internal dan factor eksternal. Faktor internal yang meliputi kecerdasan, bakat, minat, motivasi, kondisi psikis, kondisi fisik dan kemauan belajar. Adapun faktor eksternal meliputi lingkungan keluarga, lingkungan sekolah, dan lingkungan sosial (Suan, 2013: 27).

Gaya belajar visual merupakan salah satu gaya belajar yang mempengaruhi prestasi belajar siswa. Hasil penelitian menunjukkan bahwa gaya belajar visual memiliki hubungan positif dengan prestasi belajar, koefisien gaya belajar visual sebesar 0,127 ; artinya semakin tinggi penggunaan gaya belajar visual maka semakin tinggi prestasi belajar siswa. Hasil penelitian ini menunjukkan bahwa pengaruh gaya belajar visual terhadap prestasi belajar berada pada kategori cukup kuat (Sugiyono, 2007 dalam Priyatno, 2008: 78). Gaya belajar visual adalah salah satu gaya belajar siswa yang pada dasarnya lebih menekankan pada bagaimana seorang siswa lebih mudah mempelajari materi pelajarannya melalui melihat, memandangi, atau mengamati objek belajarnya. 
Hal tersebut bertujuan untuk membantu siswa memusatkan perhatiannya untuk memahami materi yang dipelajarinya. Pemutusan perhatian terhadap objek yang dipelajari sangat penting agar siswa dapat memahami materi tersebut. Perhatian itu merupakan reaksi umum organisme dan kesadaran yang menyebabkan bertambahnya aktivitas, daya konsentrasi dan pembatasan kesadaran terhadap suatu obyek (Kartono, 1996:111). Gaya belajar visual memembantu siswa memusatkan perhatian dan konsentrasi terhadap materi yang dipelajari melalui melihat, memandangi, atau mengamati materi pelajaran tersebut. Dengan melihat, mamandangi, dan mengamati objek yang dipelajari saat membacanya, membantu siswa memusatkan perhatian dan konsentrasi terhadap materi belajarnya sehingga siswa akan lebih mudah memahami materi tersebut. Hal ini didukung oleh pendapat Ahmadi dan Supriyono (2004: 84) yang mengemukakan bahwa seseorang yang bertipe visual akan cepat mempelajari bahan-bahan yang disajikan secara tertulis, bagan, grafik atau gambar, atau dengan kata lain lebih mudah mempelajari bahan pelajaran yang dapat dilihat dengan alat penglihatannya.

Gaya belajar visual membuat siswa belajar melalui melihat, memandangi, mengamati, dan sejenisnya. Lebih tepatnya, gaya belajar visual adalah belajar dengan melihat sesuatu, baik melalui gambar atau diagram, pertunjukkan, peragaan, atau video (Ula, 2013). Teori belajar behaviorisme turut mendukung gaya belajar visual. Belajar merupakan akibat dari adanya stimulus dan respons. Pemberian informasi melalui gambar atau diagram merupakan stimulus dalam gaya belajar visual sebagai respons dari penerimaan informasi ini adalah prestasi belajar dari siswa tersebut. Gaya belajar visual membantu siswa/ma- hasiswa mengingat materi pelajaran yang langsung dilihat sehingga hal tersebut ber- pengaruh positif terhadap prestasi belajar yang diperoleh (Mulyono, dkk., 2007). Teori-teori di atas mendukung hasil penelitian ini, gaya belajar ${ }^{1}$ visual (X1) merupakan salah satu faktor penting yang berpengaruh terhadap prestasi belajar siswa (Y). Hasil penelitian menunjukkan bahwa variabel gaya belajar visual (X1) memiliki pengaruh sebesar 66,55\% terhadap variabel prestasi belajar (Y) siswa pada Jurusan IPA SMA Dian Andalas Padang Tahun Ajaran 2019/2020.

Gaya belajar auditorial merupakan salah satu gaya belajar yang dimiliki siswa yang mempengaruhi prestasi belajar siswa. Hasil penelitian menunjukkan bahwa gaya belajar auditorial memiliki hubungan positif dengan prestasi belajar, koefisien gaya belajar auditorial sebesar 0,166 , artinya semakin tinggi penggunaan gaya belajar auditorial maka semakin tinggi prestasi belajar siswa. Hasil penelitian ini menunjukkan bahwa pengaruh gaya belajar auditorial terhadap prestasi belajar berada pada kategori cukup kuat (Sugiyono dalam Priyatno, 2008: 78). Gaya belajar auditorial lebih mengedepankan indra pendengar. Belajar melalui mendengar sesuatu dapat dilakukan dengan mendengarkan kaset audio, ceramah, diskusi, debat, dan instruksi (perintah) verbal (Ula, 2013).

Siswa dengan gaya belajar auditorial lebih mudah mencerna, mengolah, dan menyampaikan informasi dengan jalan mendengarkan secara langsung. Mereka cenderung belajar atau menerima informasi dengan mendengarkan atau secara lisan. Siswa dengan gaya belajar auditorial memiliki kekuatan pada kemampuannya untuk mendengar. Bagi siswa yang memiliki gaya belajar auditorial, telinga merupakan salah satu alat indra yang berperan penting karena dalam telinga terdapat daun telinga, lubang telinga, gendang pendengar, palu pendengar, paron atau landasan, dan sang gurdi. Gendang pendengar menyampaikan getaran pada tulang pendengar (palu, paron dan sanggurdi), sedangkan telinga yang sebenarnya terdiri atas liku-liku, rumah siput dan tiga buah kanal berbentuk setengah lingkaran. Alat telinga ini berguna untuk menyampaikan perangsang-perangsang suara pada kulit otak, dan rangsangan tersebut diolah di dalam otak sebagai suatu infor- masi (Kartono, 1996: 39).

Dengan gaya belajar auditorial, menyerap dan mengolah informasi dengan kemampuan mendengar yang baik dalam upaya mencapai prestasi belajar yang baik pula. Teori-teori di atas mendukung hasil penelitian ini, gaya belajar auditorial (X2) merupakan salah satu faktor penting yang berpengaruh terhadap prestasi belajar siswa (Y). Hasil penelitian menunjukkan bahwa variabel gaya belajar auditorial (X2) memiliki pengaruh sebesar 70,85\% terhadap variabel prestasi belajar (Y) siswa pada Jurusan IPA SMA Dian Andalas Padang Tahun Ajaran $2019 / 2020$. 
Gaya belajar kinestetik merupakan salah satu gaya belajar yang dimiliki siswa yang mempengaruhi prestasi belajar siswa. Hasil penelitian menunjukkan bahwa gaya belajar kinestetik memiliki hubungan positif dengan prestasi belajar. Hal ini ditunjukkan dengan koefisien gaya belajar kinestetik sebesar 0,148 , artinyasemakintinggi penggunaan gaya belajar kinestetik maka semakin tinggi prestasi belajar siswa. Hasil penelitian ini menunjukkan bahwa pengaruh gaya belajar kinestetik terhadap prestasi belajar berada pada kategori cukup kuat (Sugiyono, 2007 dalam Priyatno, 2008: 78).

Gaya belajar kinestetik adalah belajar melalui aktivitas fisik dan keterlibatan langsung, yang dapat berupa "menangani" bergerak, menyentuh, dan merasakan/mengalami sendiri (Ula, 2013). Siswa yang memiliki kecenderungan dengan ciri gaya belajar kinestetik lebih menyukai belajar atau menerima informasi melalui gerakan atau sentuhan. Siswa dimungkinkan untuk mencapai prestasi belajar yang efektif melalui gerakan atau sentuhan secara langsung berdasarkan ciri gaya belajar kinestetik. Siswa dengan gaya belajar kinestetik seringkali mengeluarkan ungkapan seperti, „rasanya hal itu ada benarnya"e, „saya kesulitan menangani masalah itu", „,coba beri saya contoh konkretnya", ,saya masih belum menemukan kepastian", „sepertinya kata-kata orang itu bisa saya pegang" atau" biarkan saya mencobanya dulu sebelum memberi kesimpulan". Kalimat-kalimat seperti ini sering digunakan oleh siswa yang memiliki gaya belajar kinestetik, karena hal tersebut menunjukkan keinginan mereka untuk melakukan sesuatu yang ingin mereka ketahui atau pelajari secara langsung.

Bagi siswa dengan gaya belajar kinestetik, kondisi fisik merupakan salah satu faktor yang berperan penting, karena mereka akan langsung melakukan tindakan secara fisik dalam kegiatan belajar mereka. Jika ia belajar dengan kondisi fisik yang sehat, proses dan hasil belajarnya akan lancar dan maksimal. Berbeda halnya dengan seseorang yang belajar dengan kondisi fisik yang kurang atau bahkan tidak sehat, proses dan hasil belajarnya akan terganggu. Di samping itu, ia akan lebih cepat merasa lelah, tidak bersemangat, mudah pusing, mudah mengantuk jika badannya lemah, dan sulit menerima pelajaran. Hal ini akan membawa pengaruh negatif pada hasil belajarnya (Ula, 2013: 18-19). Demikian juga seseorang yang belajar dalam keadaan yang lelah, ia tidak dapat menjalankan proses belajar dengan baik dan hasil belajarnya pun tidak akan sempurna. Dengan kata lain, siswa yang sakit akan mengalami kelelahan fisiknya sehingga saraf sensoris dan motorisnya lemah (Zagoto, dkk., 2019).

Demikian juga siswa yang kurang sehat akan mengalami kesulitan belajar, sebab ia mudah lelah, mengantuk, pusing, kurang semangat, dan kehilangan konsenterasi be- lajarnya (Ahmadi \& Supriyono, 2004: 79). Dengan melakukan langsung sesuatu yang dipelajari, seorang siswa akan selalu mengingat pengalaman belajar tersebut dan akan berdampak positif pada prestasi belajarnya (Tanta, 2010). Hal inilah yang menunjukkan bahwa gaya belajar kinestetik memiliki pengaruh terhadap prestasi belajar siswa. Teori-teori di atas mendukung hasil penelitian ini, yaitu gaya belajar kinestetik (X3) merupakan salah satu faktor penting yang berpengaruh terhadap prestasi belajar siswa (Y). Hasil penelitian menunjukkan bahwa variabel gaya belajar kinestetik (X3) memiliki pengaruh sebesar $69,54 \%$ terhadap variabel prestasi belajar (Y) siswa pada Jurusan IPA SMA Dian Andalas Padang Tahun Ajaran 2019/2020 (Zagoto, dkk., 2018; Sarumaha, 2018; Dakhi, O., 2013).

\section{SIMPULAN}

Kesimpulan yang dapat ditarik dari hasil penelitian dan pembahasan di atas adalah gaya belajar visual, gaya belajar auditorial, dan gaya belajar kinestetik secara simultan/bersama-sama maupun secara terpisah/masing-masing dapat mempengaruhi prestasi belajar siswa pada Jurusan IPA SMA Dian Andalas Padang Tahun Ajaran 2019/2020. Berdasarkan hasil penelitian ini dapat disarankan bagi beberapa pihak, sebagai berikut.

Pertama, bagi siswa, agar lebih mengenal dan memahami karakteristik dari gaya belajar mereka sehingga dapat melakukan kegiatan belajar dengan baik sesuai gaya belajarnya dan menghasilkan prestasi belajar yang baik pula. Kedua, bagi guru, agar lebih mengenal dan memahami karakteristik dari gaya belajar siswa sehingga dapat disesuaikan dengan gaya pembelajaran guru. Ketiga, bagi sekolah, agar memperhatikan gaya belajar siswa yang mempengaruhi prestasi belajarnya, baik gaya belajar visual, auditorial, dan kinestetik sehingga 
dapat disesuaikan dengan gaya pembelajaran guru dan kondisi sekolah maupun sarana serta prasarana sekolah dalam menunjang peningkatan prestasi belajar siswa pada sekolah tersebut. Keempat, bagi masyarakat, agar lebih menciptakan suasana yang kondusif terutama suasana yang dapat mempengaruhi prestasi belajar siswa, karena lingkungan masyarakat juga dapat berpengaruh terhadap prestasi belajar siswa. Kelima, bagi instansi terkait, baik instansi pemerintah maupun yayasan-yayasan swasta yang bergerak dalam bidang pendidikan agar lebih memperhatikan hal- hal yang mendukung siswa sehingga dapat mengembangkan gaya belajar yang dimilikinya. Misalnya, terawatnya fasilitas-fasilitas seperti perpustakaan daerah, laboratorium, dan taman baca bagi siswa. Keenam, akademisi yang akan melakukan penelitian lanjutan maupun yang sejenis dengan pene- litian ini, agar lebih memperhatikan gaya belajar siswa yang mempengaruhi prestasi belajar siswa, baik gaya belajar visual, gaya belajar auditorial, dan gaya belajar kinestetik.

\section{DAFTAR PUSTAKA}

Ahmadi, H, A. dan Supriyono W. 2004. Psikologi Belajar Edisi Revisi. Jakarta: PT. Rineka Cipta.

Dakhi, O. "Aplikasi Pendeteksian Kerusakan File Akibat Virus Dengan Menggunakan Metode Heuristic." Pelita Informatika Budi Darma, vol. 4, no. 1, pp. 35-41, 2013.

Dakhi, O. 2013. Belajar Javascript Dengan Mudah Dan Detail. Jakarta: Dapur Buku. pp. 1-202.

DePorter, B. \& Hernacki, M. 2000. Quantum Learning. Edisi Revisi. Bandung: Kaifa. Hamalih, O.H. 2001. Proses Belajar Mengajar. Bandung: PT. Remaja Rosda Karya. Hasrul. 2009. "Pemahaman Tentang Gaya Belajar". Jurnal Medtek, 1(2), Oktober 2009.

Kartono, K. 1996. Psikologi Umum. Bandung: Mandar Maju.

Mulyono, W.A. Purwandari H., dan Permana, R.H. 2007. "Pengaruh Pelatihan Gaya Belajar Terhadap Peningkatan Indeks Prestasi Mahasiswa". Jurnal Keperawatan Soedirman (The Soedirman Journal of Nursing), 2(3) November 2007.

Priyatno, D. 2008. Mandiri Belajar SPSS. Yogyakarta: Media Kom.

Sarumaha, R., Harefa, D., \& Zagoto, Maria M. (2018). Upaya Meningkatkan Kemampuan Pemahaman Konsep Geometri Transformasi Refleksi Siswa Kelas XII-IPA-B SMA Kampus Telukdalam Melalui Model Pembelajaran Discovery Learning Berbantuan Media Kertas Milimeter. Jurnal Education and development, Vol.6 No.1, 90-96. https://doi.org/10.37081/ed.v6i1.668

Suan, E.B. 2013. "Analisis Faktor-Faktor yang Mempengaruhi Prestasi Belajar Siswa SMP pada Panti Asuhan di Kota Kupang pada Semester Ganjil Tahun Ajaran 2012/2013". Tesis. Program Pascasarjana Undana.

Tanta. 2010. "Pengaruh Gaya Belajar Terhadap Hasil Belajar Mahasiswa Pada Mata Kuliah

Biologi Umum Program Studi Biologi Universitas Cendrawasih". Jurnal Kependidikan Dasar, 1(1), September 2010.

Ula, S.S. 2013. Revolusi Belajar: Optimalisasi Kecerdasan Melalui Pembelajaran Berbasis Kecerdasan Majemuk. Yogya- karta: Ar Ruzz Media.

Zagoto, Maria M., Yarni, Nevi; Dakhi, O. (2019). Perbedaan Individu dari Gaya Belajarnya Serta Implikasinya Dalam Pembelajaran. Jurnal Review Pendidikan dan Pengajaran, 2(2), 259265.

Zagoto, Maria M. \& Dakhi, O (2018). Pengembangan Perangkat Pembelajaran Matematika Peminatan Berbasis Pendekatan Saintifik Untuk Siswa Kelas XI Sekolah Menengah Atas. Jurnal Review Pendidikan dan Pengajaran, 1(1), 157-170.

Zagoto, Maria M. (2018). Pengembangan Perangkat Pembelajaran Matematika Berbasis Realistic Mathematic Educations Untuk Siswa Kelas V Sekolah Dasar, Jurnal Education And Development, vol. 3, no. 1, p. 53, Feb. 2018. https://doi.org/10.37081/ed.v3i1.139 